IBAD, 2020; (Özel Sayı): 229-243

\title{
KKTC Ortaöğretim Kurumlarında 2020-2025 Yılları Arasında Olası Pandemi Sürecinde Öngörülen Stratejik Plan Çalışması
}

\author{
Doç. Dr. Veclal Gündüz ${ }^{*}$ \\ Gaye Türker ${ }^{2}$ \\ Halide Karabekir ${ }^{3}$ \\ Hülya Altun ${ }^{4}$
}

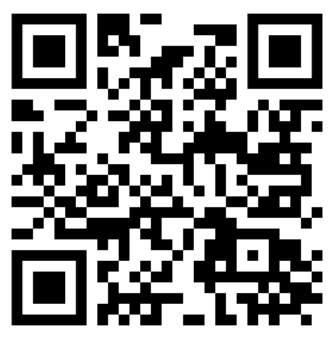

Geliş tarihi: 19.09 .2020

Kabul tarihi: 28.10 .2020

\section{Atıf bilgisi:}

IBAD Sosyal Bilimler Dergisi

Sayı: Özel Say1 Sayfa: 229-243

Yil: 2020

This article was checked by iThenticate. Similarity Index 20\%

Bu makalede araştırma ve yayın etiğine uyulmuştur.

1 Bahçeșehir Kıbrıs Üniversitesi, KKTC, veclal.gunduz@baucyprus.edu.tr,

ORCID ID: 0000-0002-6002-582X

2 Atleks Sanverler Ortaokulu, KKTC, gturker.turker@gmail.com,

ORCID ID: 0000-0002-6799-2123

3 Aydınköy İkokulu, KKTC,

ORCID ID: 0000-0003-4719-4378

${ }^{4}$ Güzelyurt Türk Maarif Koleji, KKTC, hulyametti@yahoo.com,

ORCID ID: 0000-0003-4507-8269

* Sorumlu yazar öz

$\mathrm{Bu}$ çalışmanın amacı Kuzey Kıbrıs Türk Cumhuriyeti (KKTC) Ortaöğretim Kurumlarında 2020-2025 yılları arasında olası Pandemi sürecinde ortaöğretim kurumlarındaki Stratejik Plan örneği hazırlamaktır. Yeni tip Coronavirus (Covid -19) pandemisinin kontrol altına alınmasına yönelik tedbirler kapsamında dünya genelinde insanların evlerinde kalmalarına dönük uygulamalar devreye girerken bu yeni durum birçok ülkede ortaöğretim kurumlarının yeni stratejiler geliştirmesine yol açmıştır. Son dönemde yapılan araștırmalarda stratejik planlama yapan okulların Covid-19 pandemisini daha rahat geçirdiklerini göstermiştir. $\mathrm{Bu}$ okullar stratejik planlama yaparak büyük başarılara imza atmış ve kendi kategorisindeki diğer okulların önüne geçerek belirgin şekilde fark yaratmışlardır. COVID-19'la Hızlı Mücadele Taslağı Harvard Eğitim Enstitüsündeki Küresel Eğitim İnovasyon Girişimi ve Avrupa Ekonomik İşbirliği Teşkilatı (OECD, 2020) Eğitim ve Beceri Direktörlüğü, hükümetlerin COVID-19 pandemisine karşı eğitim politikaları hazırlamalarını desteklemek için bir karar destek taslağının gelistiririlmesinde işbirliği yapmaktadır. $\mathrm{Bu}$ araştırmada nitel araştırma yöntemleri kullanılmıştır. Örneklem seçiminde de amaçlı örnekleme, maksimum çeşitlilik örnekleme yönteminden yararlanılmıştır. Maksimum çeşitlilik örneklemesi temelinde yaş cinsiyet, kıdem yılı, eğitim düzeyi gibi özelliklere dikkat edilerek araştırmanın katılımcıları belirlenmiştir. Çalışma grubu Güzelyurt Bölgesi ortaöğretim kurumları olarak belirlenmiştir. Bu katılımcılar KKTC Güzelyurt Bölgesi ortaokul, lise ve kolejinde görev yapan 20 öğretmen, 3 müdür ve 6 müdür muavininden oluşmaktadır. Veri toplama aracı olarak yarı yapılandırılmış görüşme forumları kullanılmıştır. Veriler betimsel analiz yöntemi ile analiz edilmiş, belirlenen temalar çerçevesinde sunulmuştur. Bulgular KKTC ortaöğretim kurumlarında Pandemi sürecinde öngörülen stratejik plan örneği için eğitim sisteminde öğrenci kaynaklı, eğitim ve öğretim kaynaklı ve öğretmen kaynaklı sorunları ortaya çıkarmıștır. Bu çalışmada genel anlamda ortaöğretim kurumlarındaki Pandemi sürecinde olması gereken eğitim sistemindeki misyon, vizyon, eğitim politikaları, amaçlar, hedefler, güçlü yönler, zayıf yönler, firsatlar ve tehditler (GZFT/SWOT) ve politik, ekonomik, sosyal ve teknolojik (PEST) analizleri ile belirlenmiştir. Bunların sonucunda da Pandemi durumunda olası stratejik plan örneği sunulmuştur. Bu çalışma sonucunda KKTC ortaöğretim kurumlarında olası pandemi sürecinde çevresel faktörleri ve paydaşların mevcut potansiyellerini de dikkate alarak stratejik planlama yapmanın önemi vurgulanmıştır.

Anahtar Kelimeler: Stratejik Plan, SWOT, PEST, Pandemi, KKTC. 


\title{
Strategic Plan Study Foreseen in The Possible Pandemic Period Between 2020-2025 in TRNC Secondary Education Institutions
}

\author{
Assoc. Prof. Dr. Veclal Gündüz ${ }^{*}$ \\ Gaye Türker ${ }^{2}$ \\ Halide Karabekir ${ }^{3}$ \\ Hülya Altun ${ }^{4}$
}

First received: 19.09 .2020

Accepted: 28.10 .2020

Citation:

IBAD Journal of Social Sciences

Issue: Special Issue Pages: 229-243

Year: 2020

This article was checked by iThenticate. Similarity Index 20\%

1 Bahçeşehir Cyprus University, TRNC, veclal.gunduz@baucyprus.edu.tr, ORCID ID: 0000-0002-6002-582X

2 Atleks Sanverler Ortaokulu, TRNC, gturker.turker@gmail.com,

ORCID ID: 0000-0002-6799-2123

3 Aydınköy İlkokulu, TRNC, halide.karabekir@gmail.com, ORCID ID: 0000-0003-4719-4378

4 Güzelyurt Türk Maarif Koleji, TRNC, hulyametti@yahoo.com, ORCID ID: 0000-0003-4507-8269

* Corresponding Author

\begin{abstract}
The aim of this study is to prepare a Strategic Plan sample in secondary education institutions in the Turkish Republic of Northern Cyprus (TRNC) Secondary Education Institutions between 2020 and 2025 during the possible Pandemic period. The new type of coronavirus (Covid -19) pandemic of control under taken for measures within the scope of the world in general people in their homes leaving them facing applications circuit when entering this new situation in many countries secondary education the institutions new strategies to improve road paved. Last in the period made in research Strategic planning makes the school Covidien-19 the pandemic more comfortable that they had shown. These schools are strategic planning making great achievements signature tossed and own the category other schools before passing pronounced as differences have created. Covidien-19 to speed Fighting Draft Harvard Education at the Institute of Global Education Innovation Initiative and the European Economic Cooperation Organization (OECD) Education and Skills Directorate, Government of Covid-19 to the pandemic against the education policies to prepare support for a decision supporting the draft in the development cooperation serves. Qualitative research methods were used in this research. Sample the selection also for sampling, the maximum variety sampling the method was used. Based on the maximum diversity sampling, the participants of the research were determined by paying attention to features such as age, gender, year of seniority and education level. The working group has been determined as Güzelyurt Region secondary education institutions. These participants TRNC Morphou District middle school, high school and in college a task that 20 teachers, three managers and six managers from the assistant is made. Semi- structured interview forums are used as a data collection tool. Data descriptive analysis method with analysis was determined within the framework presented. Results TRNC secondary institutions pandemic in the process envisaged strategic plan examples for the education system students welded, training and teaching originated and teacher -induced problems occur. In this study, the overall sense of secondary education in institutions pandemic in the process of being required training on the system's mission, vision, education policies, objectives, goals, strength, weaknesses, opportunities and threats (SWOT) and political, economical, social and technological (PEST) analysis and determination. As a result, an example of a possible strategic plan is presented in the case of Pandemic. This work resulted in the TRNC secondary education in institutions of possible pandemic in the process of environmental factors and the stakeholders present their potential also consider taking strategic planning to do importance is emphasized.
\end{abstract}

Keywords: Strategic Plan, SWOT, PEST, Pandemic, TRNC 


\section{GíRiş}

Korona virüsün (Covid-19) dünyada yarattığı olumsuz etkiler yüzünden stratejik planlar önem kazanmıştır. KKTC Ortaöğretim kurumlarında da stratejik planlamanın yapılmasını zorunlu kılmıştır. Okullarda, stratejik planlamanın temel amacı; okulun bulunduğu çevreyi araştırmak, incelemek, okulun geleceğini tahmin etmek ve bu tahminler doğrultusunda kaynakları etkin kullanabilmektir (Bell, 2004). Bu yönüyle stratejik planlama, katı kuralları olmayan, sadece önsezilere dayanmayan, ardıl ve yetkeci olmayan bir süreçtir (Nartgün, 2004). Bu süreç, strateji seçeneklerini oluşturma ve değerlendirme, stratejiyi seçmek ve uygulamaya koymak için ayrıntılı bir plan oluşturmayı kapsar (Aksu, 2002).

Pandemi döneminde stratejik planlama yapma nedeni ileriye yönelik (uzun dönemli), planlar, politikalar üretme, bu dönemi sorunsuz atlatma, amaç ve araç uygunluğunu sağlama, eldeki güçlerin etkin kullanımını gerçekleştirme, esnek ve tedbirli olma gibi ilkeleri de içeren bir anlayışı içinde stratejik plan örneği sunmaktır.

COVID-19 olarak bilinen, 2019 yılında bulaşıcı hastalığa neden olan yeni Coronavirus. SARS-CoV-2, şiddetli akut solunum yolu sendromu Coronavirus-2'nin kısaltmasıdır. Bu hastalık 11 Şubat 2020'de Dünya Sağlık Örgütü tarafından resmen COVID-19 olarak adlandırılmıştır. 19 ilk tanımlandığı yılı temsil eder (2019). İnsanlarda hafif üst solunum yolu hastalıklarına neden olduğu bildirilen yeni bir hastalıktır. DSÖ tarafindan 11 Mart 2020'de salgın ilan edildi. COVID-19 Pandemisinin dünya üzerindeki etkileri bir yana çocukların ve gençlerin eğitimlerinde oluşabilecek açıkların önüne geçmek için izlenecek yolların belirlenip gerekli adımların hızla atılması büyük önem taşımaktadır.

II. Dünya Savaşı yıllarında ortaya atılmış olan stratejik planlama kavramı ilk olarak askeri alanda sonra da iş dünyasında kullanılmıştır. Yükseköğretimde 1970'li yıllarda, diğer okul düzeylerinde ise 1980'li yıllardan sonra kullanılmaya başlamıştır (Reiger, 1993).

İdarenin hedeflerini ve bu hedeflere ulaşmak için izlenecek yolu tanımlayan stratejik plan bu süreçte idarenin tüm birimlerine görevler verir. İlk olarak idarenin her bölümü, planlama için gerekli olan bilgileri toplar ve her yöneticisi kendi bölümüne düşen görevleri belirler, böylece tüm örgütün katkılarıyla stratejik plan hazırlanır (Gönüllü, 2008).

Kurumlar değişime uyum sağlamada yeni stratejiler belirlemek durumundadırlar. Stratejisi olmayan kurumlar veya stratejisi belirleyemeyen kurumlar gelecek için kendilerinden emin olamayacaklardır. Çünkü kurumun geleceği önceden planlanmamış ve belirsizlik içinde kalmıştır. Bu durumda da başarısızlık doğal bir sonuç olacaktır. Bu çalışmamızdaki amacımız KKTC Ortaöğretim Kurumlarında 2020-2025 yılları arasında olası Pandemi Sürecinde öngörülen Stratejik Plan nasıl olmalıdır. Bu çalışmanın amacı KKTC Ortaöğretim Kurumlarında 2020-2025 yılları arasında olası Pandemi Sürecinde öngörülen Stratejik Plan örneğini hazırlamaktır. Bu çalışma COVID-19 Pandemisine karş1 etkili bir eğitim sürdürebilmek için izlenecek olan yol haritasını belirlemeyi amaçlamaktadır. Bu çalışmada Pandemi sürecinde olası stratejik planı üç ana başlık altında incelenmiştir.

- Eğitim ve öğretime erişim nasıl olmalıdır?

- Stratejik planla eğitim ve öğretimde kalite nasıl arttırılmalıdır?

- Stratejik plan ile kurumsal kapasite nasıl olmalıdır?

Bu sorunların çözümü ile KKTC ortaöğretim kurumlarında eğitim ve öğretime kolay erişimi sağlama, eğitim ve öğretimin kalitesini artırma ve kurumsal kapasite artırımı sağlanabilir.

\section{LITERATÜR TARAMASI}

\subsection{Stratejik Planlama}

Aksu (2002) yapmış olduğu çalışmada stratejik planlamayı dört temel yarara bağlamaktadır. Birinci yararı stratejik düşünmeyi ve stratejik uygulama geliştirmeyi sağlamasıdır. İkinci yararı karar verme sürecini geliştirir. Üçüncü yarar, oluşabilecek durumlara karşı kurumların hızlı hareket ederek başa çıkması 
sağlanır. Son yararı ise kurumlarda çalışan kişilerin takım çalışmasını sağlayarak kurum üyelerinin uzmanlaşarak güçlenmesini sağlar.

Stratejik amaca uygun geliştirilen planlar gerçek verilere göre hazırlanmalıdır. Okullardaki stratejik planlama faaliyetlerinde ve okullar için geliştirilen stratejik planların hazırlanmasında, okulların iç paydaşları olan okul yönetici, öğretmenlerinin ve dış paydaşları olan veliler, okul aile birliği üyelerinin stratejik planlamaya ilişkin algıları ve inançları oldukça etkili olmaktadır. (Memduhoğlu, Uçar 2012). Bu amaçla, okullarda pandemi sürecinde stratejik planlama algısını belirlemeyi ve stratejik planlama uygulamalarını bütüncül olarak değerlendirmeyi sağlayacak çalışmalara gereksinim duyulduğu söylenebilir.

Yanpar, Kılıç ve Üredi (2010) yapmış olduğu çalışmada vurgulandığı gibi günümüzde, kurumlarda stratejik planlama yapmak yasal zorunluluk haline getirilmiştir. Aynı zamanda stratejik planlama faaliyetleri kapsamında okulun içinde bulunduğu durumu analiz etmeye yarayan tekniklerden biri olan güçlü yönleri, zayıf yönleri, firsatları ve tehditleri (GZFT) analizi hakkında da bilgi toplanması amaçlanmıştır.

OECD raporuna göre Covid 19 öğrenciler için ciddi öğrenme kayıplarına neden olmadan, öğrenme firsatlarını korumak için planlı ve etkili bir stratejik plan geliştirilmeli ve stratejiyi yönlendirecek ilkeler belirlenmelidir. Örnek verecek olursak öğrencilerin, öğretmenlerin ve hizmetlilerin sağlı̆̆ını korumak, öğrencilerin eğitimini sağlamak, öğrencilere ve öğretmenlere ve gerekirse velilere duygusal destek sağlamak şeklinde yer alan ilkelerdir. Bu ilkeler, öncelik olarak yapılması gerekenlere odaklanmasını sağlayacak, zaman ve diğer sınırlı kaynakların önceliklendirilmesine yardımcı olacaktır (OECD, 2020). Etkili bir örgüt ve okul olma okulun doğasına uygun stratejik planı, çevresel çözümlemeleri, stratejik hedefleri, faaliyet programlarını, değerlendirme ve biçimlendirme faaliyetlerini gerektirir (Arabacı, 2018).

Uygulanan sistem nedeni ile çoğu iş yeri ve okullar internet aracılığıyla işlerine ve eğitime devam etmiştir. Bu dönem zarfında internetin hem çeşitli aktivitelerle psikolojimiz üzerinde olumlu hem de eğitim ve iş alanlarında büyük katkısı olmuştur. İnternet kullanımı ve çeşitli internet araçları ile kullanılan mecralar, elektronik aletler hayatlarımıza girişimci kişiler aracılığı ile girmiş ve bize ulaşmıştır, eğer günümüzde internet ve elektronik aletler olmasaydı pandemi sürecini evlerimizden bu kadar kolay bir şekilde geçiremezdik (Reimers \& Schleicher, 2020).

\subsection{Stratejik Yönetim}

Stratejik yönetim için ilk aşamada süreci yürütecek ve yönlendirecek kurulların görev ve fonksiyonlarının belirlenmesi; ikinci aşamada Ne? ve Niçin? sorularının analiz edilmesi gereklidir. İkinci aşamada en önemli unsur stratejik yönetimi uygulamak zorunda olduğumuzu ortaya koymamızdır. Organizasyonun ne durumda olduğunu analize imkan verecek SWOT analizinin ve PEST analizinin yapılması gerekir. Üçüncü aşamada, stratejik yönetimi uygulayarak nereye ulaşmak istediğimizi vizyon ve misyon bildirgeleri hazırlayarak belirlememiz gerekir. Dördüncü aşamada, istediğimiz hedefe nasıl ulaşabileceğimize ilişkin stratejileri tespit etmek durumundayız. Bu aşamada rekabet ve portföy analizlerinden yararlanılarak strateji seçimlerinin yapılması önem taşıyor. Son olarak, uygulanan planın gözden geçirilmesi ve gerekirse planda bazı değişiklikler yapılması gerekir (Aktan, 2008). Tüm bu aşamalar Stratejik Yönetim Süreci olarak Tablo 1 'de ayrıntılı olarak gösterilmiştir. 
Tablo 1. Stratejik Yönetim Süreci Aşamaları

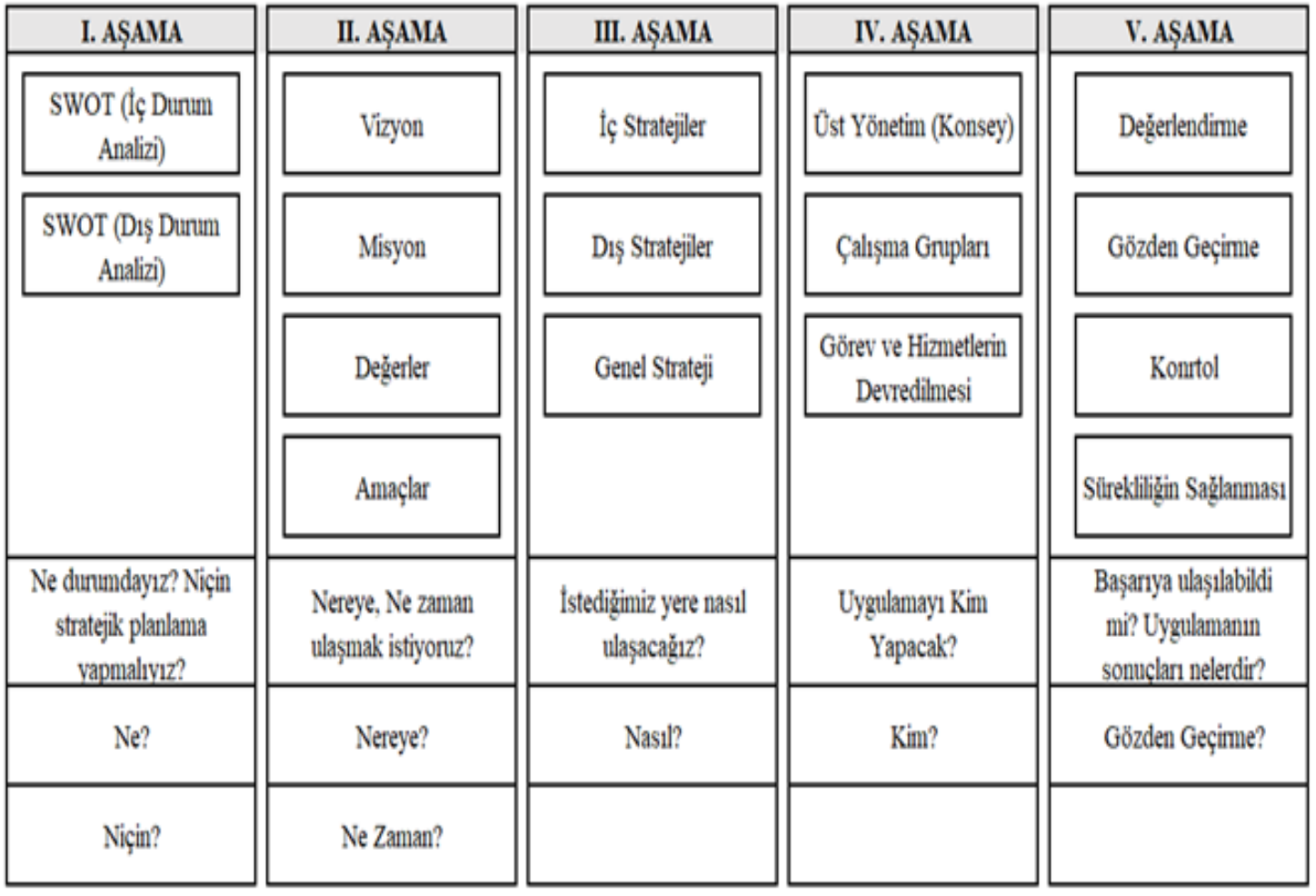

Kaynak: Aktan (1997)

Stratejik yönetimin etkili olması için kurumlar stratejik düşünebilecek ve stratejik yönetimi başarıyla uygulayabilecek liderlere ihtiyaç duyar. Öncelikle bir liderin vizyon ve misyonu olması gerekmektedir. Vizyonu ve misyonu olmayan bir liderin stratejik düşünebilme yeteneği sınırlıdır. Stratejik yönetimin organizasyonda uygulanması için üst yönetimde Stratejik Yönetim adı altında bir kurul oluşturulmalıdır. Bu kurul bünyesinde organizasyonun başında bulunan lider ve üst düzey yöneticiler görev yapmalıdır (Aktan, 2008).

\subsection{Pest Analizi Nedir}

Pest analizi kurumun çevre ile olan politik, ekonomik, sosyal ve teknolojik gelişmelerini gözlemlemek için yapılan bir analizdir.

P (Politic - Politik): Kurumlar üzerindeki politik etkilerin tespit edilmesi

E (Economic - Ekonomik): Kurumlar üzerindeki ekonomik etkilerin tespit edilmesi

S (Social - Sosyal): Kurumlar üzerindeki sosyal etkilerin tespit edilmesi

$\mathrm{T}$ (Technologic - Teknolojik): Kurumlar üzerindeki teknolojik etkilerin tespit edilmesi

Yazarlar/araştırmacılar tarafindan oluşturulmuş PEST Analizi aşağıda Tablo 2'de sunulmuştur. 
Tablo 2. PEST Analizi

\begin{tabular}{|c|c|}
\hline \multicolumn{2}{|c|}{ PEST ANALIZí } \\
\hline POLİTIK VE YASAL ETMENLER & EKONOMÍK ÇEVRE DEĞIŞSENI \\
\hline 1. İdlib’deki savaş durumu & $\begin{array}{l}\text { 1. Corona Virüsüne bağlı alınan ekonomik paket } \\
\text { tedbirleri. }\end{array}$ \\
\hline $\begin{array}{l}\text { 2. Ortadoğudaki savaş durumu ve buna bağlı petrol } \\
\text { rezervlerinin ve fiyatlarının durumu }\end{array}$ & 2. Bankaların faiz oranlarındaki değişiklikler \\
\hline $\begin{array}{l}\text { 3. Suriye'deki iç savaş ve bunu sonucunda oluşan } \\
\text { göçler }\end{array}$ & $\begin{array}{l}\text { 3. Firmaların sokağa çıkma yasağını bahane edip } \\
\text { işçileri işten çıkarması ve artan işsizlik durumu }\end{array}$ \\
\hline $\begin{array}{l}\text { 4. Avrupa Birliğinde değişen yapılar ve buna bağl1 } \\
\text { ülkelerin aldığı kararlar }\end{array}$ & $\begin{array}{l}\text { 5. Ülkeye giriş ve çıkışların kapatılmasıyla oluşan } \\
\text { ekonomik çöküş. }\end{array}$ \\
\hline $\begin{array}{c}\text { SOSYAL VE KÜLTÜREL ÇEVRE } \\
\text { DEĞISSKENI }\end{array}$ & TEKNOLOJİK ÇEVRE DEĞIŞKENİ \\
\hline $\begin{array}{l}\text { 1. Ortadoğu'daki savaşlar sonrası mültecilerin } \\
\text { Avrupa ülkelerine artan göç istekleri }\end{array}$ & $\begin{array}{l}\text { 1. MEB, Özel okullar ve üniversitelerin online } \\
\text { eğitime geçmeleri }\end{array}$ \\
\hline $\begin{array}{l}\text { 2. Mültecilerin durumuna göre hızla yükselen } \\
\text { nüfus }\end{array}$ & $\begin{array}{l}\text { 2. E-Öğrenme Ortamları ve İnternet Olanaklarına } \\
\text { olan taleplerin artması }\end{array}$ \\
\hline 3. Toplumun hayat beklentilerinin değişmesi & $\begin{array}{l}\text { 3. Online Alışveriş, Online Ödeme gibi sistemlerin } \\
\text { yaygınlaşması }\end{array}$ \\
\hline 4. Aile Yapısının değişmesi & $\begin{array}{l}\text { 4. Hayat düzeninin değişmesine bağlı olarak } \\
\text { evlerdeki internet, bilgisayar ihtiyacı ve buna } \\
\text { paralel uygun yazıllım isteklerinin artması }\end{array}$ \\
\hline \multirow{2}{*}{$\begin{array}{l}\text { 5. Tüm dünyayı etkisi altına alan Corona Virüsü } \\
\text { nedeniyle toplumun "Evde Kal” sloganıyla tüm } \\
\text { sosyal ilişkilerinin online boyuta dönüşmesi }\end{array}$} & $\begin{array}{l}\text { 5. Okulun yeni teknolojik araçlara sahip olma } \\
\text { imkanları }\end{array}$ \\
\hline & $\begin{array}{l}\text { 6. Zoom, Skype, Microsoft Teams ve Microsoft } \\
\text { Office } 365 \text { uygulamalarının kullanımının artması }\end{array}$ \\
\hline
\end{tabular}

\subsection{Swot Analizi Nedir?}

Swot analizi bir kurumun çevre ile olan ilişkilerine önem vererek çevresel değerlendirmeler yapılmasını sağlayan bir analiz türüdür. Stratejik planlama için atılması gereken ilk adım, izlenecek ilk yol SWOT analizinin yapilmasidir.

S (Strength-Güçlü): Kurumlarda oluşabilecek olan güçlü yönlerin tespit edilmesi

W (Weakness-Zayıf): Kurumlarda oluşabilecek olan zayıf yönlerin tespit edilmesi

O (Opportunity-Fırsatlar): Kurumlarda oluşabilecek olan firsatların tespit edilmesi

$\mathrm{T}$ (Treat-Tehditler): Kurumlarda oluşacak olan tehditlerin tespit edilmesi 
Şekil 1. SWOT Analizi (Barut, 2020)

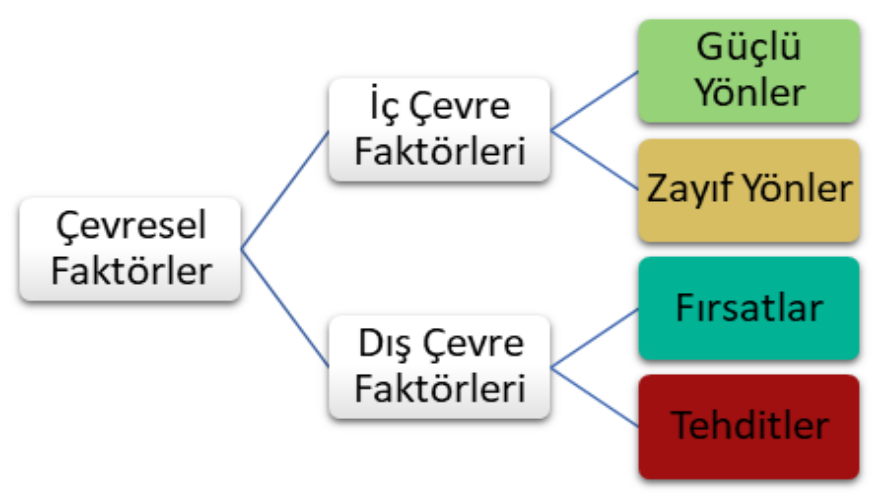

Okullarda hedeflenen başarı ve eğitim kayıplarının önlenmesi için çalışanların durumunun, çevresel faktörlerin, çalışma ortamının, teknoloji altyapısının ve çevresel kültürün dikkate alınması gerekir. Okul içi ve dışı olarak belirlenen güçlü, zayıf yönlerle, fırsatlar ve tehditler araştırmacılar tarafından oluşturulmuş olup Tablo 3.'te gösterilmiştir.

Tablo 3. Okul içi ve Okul Dışı Belirlenen SWOT Analizi

\begin{tabular}{|c|c|c|}
\hline \multicolumn{3}{|c|}{ SWOT (GZFT) ANALİŻ } \\
\hline \multirow{15}{*}{$\begin{array}{l}\mathbf{O} \\
\mathbf{K} \\
\mathbf{U} \\
\mathbf{L}\end{array}$} & GÜÇLÜ YÖNLER & ZAYIF YÖNLER \\
\hline & $\begin{array}{l}\text { 1. Sosyal, Sportif ve Kültürel Faaliyetler ve } \\
\text { başarılarla adını sıklıkla basında yer alması. }\end{array}$ & 1. Öğretmenler arası gruplaşma \\
\hline & $\begin{array}{l}\text { 2. Küçük okul olması dolayısıyla yönetiminin daha } \\
\text { kolay. (Okulun kapasitesinin dengi okullara göre } \\
\text { daha az olması.) (550). }\end{array}$ & $\begin{array}{l}\text { 2. Çalışanların değişime olan direnci (Genellikle } \\
\text { kıdemli öğretmenler karşı çıkıyor) }\end{array}$ \\
\hline & $\begin{array}{l}\text { 3. Okulun fiziki kapasitesinin yeterli olması. (Bir tek } \\
\text { kapalı spor salonu yok) }\end{array}$ & $\begin{array}{l}\text { 3. Bazı derslerde ders araç gereçlerinin yetersizliği ve } \\
\text { öğrencilerin satın alma gücünün olmaması }\end{array}$ \\
\hline & $\begin{array}{l}\text { 4. Personelinin yasal hak ve sorumluluklarına dikkat } \\
\text { edilmesi }\end{array}$ & \multirow{2}{*}{$\begin{array}{l}\text { 4. Öğretmenlerin ve Yöneticilerin akıllı tahta ve diğer } \\
\text { teknolojik aletleri etkili kullanamamaları }\end{array}$} \\
\hline & \multirow[t]{5}{*}{ 5. Okulun tarihsel geçmişinin olması. } & \\
\hline & & 5. Öğretmenler arasında yeterli işbirliğinin olmaması \\
\hline & & $\begin{array}{l}\text { 6. Okulun teknolojiyi takip edebilmesi için internetin } \\
\text { güçlü olması gerekir (altyapı) Bunun için fiber optik } \\
\text { kablolar döşenmelidir. }\end{array}$ \\
\hline & & 7. Okulun Örgüt kültürü ve ikliminin yeterli olmaması \\
\hline & & 8. Öğretmenlerin Ders programlarındaki sıkıntılar \\
\hline & \multirow{3}{*}{$\begin{array}{l}\text { 6. Bakanlığın kurduğu Moodle sistemi (Uzaktan } \\
\text { Eğitim) sistemi ve satın almış olduğu Smartschool } \\
\text { programı ile öğretmenlerin sınav notunu sisteme } \\
\text { yükleyebilme ve karneleri evden oluşturabilme } \\
\text { olanağı }\end{array}$} & $\begin{array}{l}\text { 9. Yönlendirme sınavında akademik başarının düşük } \\
\text { olması }\end{array}$ \\
\hline & & 10. Öğrenci devamsızlığının yüksek olması \\
\hline & & $\begin{array}{l}\text { 11. Özel gereksinimi olan çocuklar için tam kadrolu bir } \\
\text { özel eğitim öğretmeninin okulda bulunmaması }\end{array}$ \\
\hline & \multirow[t]{2}{*}{$\begin{array}{l}\text { 7. Çalışanlarını önemsediğini göstermek için onlara } \\
\text { (Düğün, Doğum...vs.) yardım etme }\end{array}$} & 12. Okuldaki disiplin sorunlarının fazla olması \\
\hline & & 13. Yabancı öğrencilerin dil sorunu \\
\hline & FIRSATLAR & TEHDITTLER \\
\hline
\end{tabular}




\begin{tabular}{|c|c|c|}
\hline \multirow[b]{3}{*}{ K } & 1. Dijital Eğitime geçiş & $\begin{array}{l}\text { 1. COVID } 19 \text { salgını dolayısıyla tüm ülkelerin } \\
\text { ekonomik kriz yaşaması }\end{array}$ \\
\hline & 2. MEB oluşturduğu yeni Eğitim Politikaları & 2. Salgın sonrası oluşacak İşsizlik sorunu \\
\hline & $\begin{array}{l}\text { 3. Tüm ülkelerde birlik olma ve yardıma ihtiyacı } \\
\text { olan yardım etme }\end{array}$ & $\begin{array}{l}\text { 3. Covid } 19 \text { salgınından eğitimin aksaması dolayısıyla } \\
\text { eğitim sisteminde belirsizlik süreci. (Okul sınavları, } \\
\text { Üniversite sınavı, KGS, Yönlendirme sınavları... vs) }\end{array}$ \\
\hline & $\begin{array}{l}\text { 4. Bankaların borç Faizlerini düşürmesi veya } \\
\text { ertelemesi. }\end{array}$ & 4. Bazı sektörlerde istifçi firmaların açgözlülüğü. \\
\hline & $\begin{array}{l}\text { 5. Türkiyedeki Hizmetiçi eğitim Programının } \\
\text { oradaki ögretmenler tarafindan aynen ülkemizde de } \\
\text { düzenlenebilmesi }\end{array}$ & $\begin{array}{l}\text { 5. Tüm Ülke insanlarındaki bu COVID } 19 \text { salgınından } \\
\text { ötürü psikolojik moral bozukluğu ve motivasyon } \\
\text { düșüklüğü }\end{array}$ \\
\hline & $\begin{array}{l}\text { 6. Birbirleriyle savaş durumundaki ülkelerin bile } \\
\text { Covid19 salgını dolayısıyla birbirleri ile sağlık için } \\
\text { yardımlaşması }\end{array}$ & $\begin{array}{l}\text { 6. Gelişen teknolojiyi takip etme zorunluluğuyla } \\
\text { (Online Eğitim-Alışveriş) gereken donanımı satın alma } \\
\text { gücünün olmaması (ekonomik kriz nedeniyle) }\end{array}$ \\
\hline
\end{tabular}

\subsection{Paydaş Analizi}

Kurumumuz paydaş analizi belirlemek için tüm paydaşların katılımı sağlanmış, stratejik planla ilgili görüşleri alınmıştır. Burada hedeflenen amaç stratejik planın paydaşlar tarafından benimsenmesi ve başarı düzeyinin artırılması dır. Paydaş analizinin ilk aşamasında kurumların paydaşları tespit edilmiştir. Bunun için hazırlanan Görüşme Formu Ek-1 ve Ek-2'de sunulmaktadır. Kurumun iç ve dış paydaşları görüşme formları ile saptanmıştır.

\subsubsection{Paydaşların Önceliklendirilmesi}

Paydaşlarımızla etkili bir iletişim kurulması için etki ve önem dereceleri önceliklendirilmiştir. İç ve Dış Paydaşlar etki ve önem derecesine göre Tablo 4 ve Tablo 5'te belirtilmektedir.

Tablo 4. Paydaşların Önceliklendirilmesi Etki Derecesi

\begin{tabular}{|c|c|c|c|c|}
\hline \multirow{2}{*}{ Paydaş Adı } & \multirow{2}{*}{ İç Paydaş/ Dış Paydaş } & \multicolumn{3}{|c|}{ Etki Derecesi } \\
\hline & & Zayıf & Orta & Güçlü \\
\hline Öğretmenler & İç paydaş & & & $\sqrt{ }$ \\
\hline Öğrenciler & İç paydaş & & & $\sqrt{ }$ \\
\hline Yöneticiler & İç paydaş & & & $\sqrt{ }$ \\
\hline İdari personel (sekreterler) & İç paydaş & & & $\sqrt{ }$ \\
\hline Hizmetliler & İç paydaş & & & $\sqrt{ }$ \\
\hline Kantin İşletmecisi (KTEV) & İç paydaş & & & $\sqrt{ }$ \\
\hline Milli Eğitim Bakanlığı & Diş paydaş & & & $\sqrt{ }$ \\
\hline Sendika (KTOEÖS) & Diş paydaş & & & $\sqrt{ }$ \\
\hline Okul Aile Birliği & Diş paydaş & & & $\sqrt{ }$ \\
\hline Veliler & Diş paydaş & & & $\sqrt{ }$ \\
\hline Belediye & Diş paydaş & & & $\sqrt{ }$ \\
\hline Dershaneler & Diş paydaş & & & $\sqrt{ }$ \\
\hline Mezunlar & Diş paydaş & & & $\sqrt{ }$ \\
\hline Kamu kurum ve kuruluşları & Diş paydaş & $\sqrt{ }$ & & \\
\hline Özel sektör kuruluşları & Diş paydaş & $\sqrt{ }$ & & \\
\hline Sivil toplum kuruluşları & Diş paydaş & $\sqrt{ }$ & & \\
\hline
\end{tabular}




\begin{tabular}{|l|l|l|l|c|} 
Üniversiteler & Diş paydaş & & $\checkmark$ & \\
\hline Toplum & Diş Paydaş & & & $\checkmark$ \\
\hline Diğer Okullar & Diş Paydaş & & & $\checkmark$ \\
\hline Medya & Diş Paydaş & & & $\checkmark$ \\
\hline
\end{tabular}

Tablo 5. Paydaşların Önceliklendirilmesi Önem Derecesi

\begin{tabular}{|c|c|c|c|c|}
\hline \multirow{2}{*}{ Paydaş Adı } & \multirow{2}{*}{ İç Paydaş/ Dış Paydaş } & \multicolumn{3}{|c|}{ Önem Derecesi } \\
\hline & & Zayıf & Orta & Güçlï \\
\hline Öğretmenler & İç paydaş & & & $\sqrt{ }$ \\
\hline Öğrenciler & İç paydaş & & & $\sqrt{ }$ \\
\hline Yöneticiler & İç paydaş & & & $\sqrt{ }$ \\
\hline İdari personel (sekreterler) & İç paydaş & & & $\sqrt{ }$ \\
\hline Hizmetliler & İç paydaş & & & $\sqrt{ }$ \\
\hline Kantin İşletmecisi (KTEV) & İç paydaş & & & $\checkmark$ \\
\hline Milli Eğitim Bakanlığı & Diş paydaş & & & $\sqrt{ }$ \\
\hline Sendika (KTOEÖS) & Diş paydaş & & & $\sqrt{ }$ \\
\hline Okul Aile Birliği & Diş paydaş & & & $\sqrt{ }$ \\
\hline Veliler & Diş paydaş & & & $\sqrt{ }$ \\
\hline Belediye & Diş paydaş & & $\sqrt{ }$ & \\
\hline Dershaneler & Diş paydaş & & & $\sqrt{ }$ \\
\hline Mezunlar & Diş paydaş & & $\sqrt{ }$ & \\
\hline Kamu kurum ve kuruluşları & Diş paydaş & $\sqrt{ }$ & & \\
\hline Özel sektör kuruluşları & Diş paydaş & $\sqrt{ }$ & & \\
\hline Sivil toplum kuruluşları & Diş paydaş & & $\sqrt{ }$ & \\
\hline Üniversiteler & Diş paydaş & & $\sqrt{ }$ & \\
\hline Toplum & Diş Paydaş & & & $\sqrt{ }$ \\
\hline Diğer Okullar & Diş Paydaş & & & $\sqrt{ }$ \\
\hline Medya & Dış Paydaş & & & $\sqrt{ }$ \\
\hline
\end{tabular}

\section{METODOLOJI}

\subsection{Verilerin Analizi ve Toplanması}

Bu çalışmada nitel araştırma yöntemleri betimsel ve içerik analizine tabi tutulmuştur. Görüşmeler, 2019 yılı Bahar Döneminde yapılmıştır. KKTC Milli Eğitim Bakanlığına bağlı Güzelyurt Bölgesi Ortaöğretim kurumları baz alınmıştır. Çalışma grubu, 3 Müdür, 6 Müdür Muavini ve 20 öğretmenden oluşmaktadır. $\mathrm{Bu}$ araştırmada gerekli bilgileri sağlamak için katılımcılara görüşme formu gönderilmiş cevaplar mail yolu ile geri alınmıştır. Katılımcıların verdiği cevaplar belli başlıklar altına gruplandırılıp çıkan sonuçlar Excel programı ile analiz edilmiştir.

Stratejik plan çalışması yaparken SWOT analizi, PEST analizlerinden de yararlanılmıştır. Öncelikle pandemi sürecinde kurumların Stratejik planlama çalışması için kullanılan görüşme formlarından çıkan sonuçlar betimsel olarak analiz edilmiştir. Araştırmada elde edilen verilerin içerik analizi sürecinde araştırmacılar katılımcıların Stratejik planlama ile ilgili sorun olarak belirledikleri maddeleri belirli 
başlıklar altında birleştirmişler ve alt temaları oluşturmuşlardır. Daha sonra araştırmacılar, farklı temalar altında belirledikleri görüşler üzerinde tartışarak anlaşmaya varmışlardır. Araştırmanın güvenirliği "Güvenirlik= Görüş birliği / (Görüş Birliğgi + Görüş Ayrılığı) x 100" formülü kullanılarak hesaplanmıştır (Miles ve Huberman, 1994). Araştırmacılar arasındaki güvenirlik oranı \%86 olarak bulunmuştur. Görüşme yapılırken araştırmaya katılan öğretmenlerin ve yöneticilerin dürüst ve samimi cevaplar verdikleri varsayılmıştır. Görüşme soruları ile ilgili alınan uzman görüşlerinin geçerli ve güvenilir olduğu varsayılmıştır.

Pandemi sürecini başarılı bir şekilde atlatabilmek için ortaöğretim kurumlarının geleceği bakışını değiştirecek misyon, vizyon ve değerlerini saptaması gereklidir.

\subsection{Misyon ve Vizyon Bildirgeleri}

Çalışmamızda, Ortaöğretim kurumlarının misyonunu, herkes tarafından kullanımı kolay, ulaşılabilir, ülkenin sosyo kültürel ve ekonomik gelişimine katkı sağlayacak girişimci ve yenilikçi öğrenciler yetiştirmek ve onları olası pandemi sürecinde karşılaşabilercekleri sorunlara çözümler üretebilir duruma gelmelerin sağlamaktır. Kurumların vizyonu ise ortaöğretim sınıflarından her yıl YKS'ye ilk sıralarda öğrencileri yerleşmesini sağlamak ve A-Level ve GCSE sonuçlarıyla öğrencilerin yurt dışındaki eğitim kurumlarına yerleştirilmesini sağlamak" şeklinde belirlenmiştir. Bu amaca ulaşmak çalışmamızda belirlenen temel değerleri şunlardır:

- Kurumsal bağlılık ancak çalışanların kurumuna bağlılık duygusunun yüksek olmasını ile sağlanır. Bunun için gereken ortamı hazırlarız.

- Gönüllülük için çalışanların kurumda sanki kendi işiymiş gibi çalışmaları arzu ederiz.

- Dürüstlük için her çalışanın konu ne olursa olsun dürüst olması bekleriz.

- Katılımcılık için kurumun yapacağı her türlü aktiviteye tam katılım bekleriz.

- Eğitim Kalitesi için kurumdaki her öğrenci ve öğretmenin Eğitim Kalitesinin yüksek olmasını isteriz.

- Verimlilik için Mezun öğrencilerin iyi bir iş bulması ve topluma faydalı olması bekleriz.

- Araştırmacı Kimlik için gerek öğretmen gerekse öğrencinin araştırmacı kimliğe sahip olması isteriz ve bunu destekleriz

- Sürekli gelişim sağlamak için mümkün olan koşullarda her öğrenci ve öğretmen sürekli kendini yenilemesini isteriz.

- Uyumluluk için Öğrenci ve Öğretmenlerin kurumun yapısına uyumlu hariket sergilemelerini bekleriz.

- Diğer okullardan Ayırt Edilebilir olmak için kurumu ön plana çıkaracak sosyal etkinlik ve diğer faaliyetlerin yapılmasını bekleriz.

\section{BULGULAR VE YORUMLAR}

Pandemi döneminde uzaktan eğitim ile akademik başarıyı en üst seviyede tutmak, öğrenci devamdevamsızlığı, fiziki ve teknolojik alt yapıyı güçlendirme ve tercih edilme vs gibi alanlarında toplam 10 tane amaç ve hedef belirlenmiştir. Bu amaçlar ve hedefler belirlenirken konular 3 tema altında ele alınmıştır.

\subsection{Eğitim ve Öğretime Erişim (Tema I)}

Kurumumuzda Pandemi sürecinde Eğitim ve öğretime erişim okullaşma, devam ve devamsızlık, özel eğitime ihtiyaç duyan bireylerin eğitime erişimi, yabancı öğrencilerin eğitime erişimi ve maddi durumu yetersiz olan öğrencilerin okul ihtiyaçları ve ders araç gereçlerinin karşılanması kapsamında yürütülen faaliyetlerin ele alındığ temadır.

Stratejik Amaç-1: Pandemi sürecinde kurumlarınızda eğitim ve öğretime erişimi nasıl sağladınız? 
Stratejik Hedef-1: Pandemi sürecinde öğretmenlerimiz ve öğrencilerimizin eğitime ve öğretime erişimi e-öğrenme ortamlarını, mobil iletişim cihazlarını kullanarak ve öğretmenlere yönelik hizmet içi eğitim gereksinimlerini sağlayarak yapılabilir.

Stratejik Amaç-2: Pandemi sürecinde maddi durumu yetersiz olan öğrencilerin eğitim giderleri için kaynaklar nasıl sağlanır?

Stratejik Hedef-2: Bu durumdaki öğrenciler için Milli Eğitim ve Kültür Bakanlığı, okul aile birliği ve çeşitli yardım kuruluşları ile temasa geçilip kaynak temin edilebilir.

Stratejik Amaç-3: Pandemi sürecinde özel eğitime ihtiyaç duyan öğrenciler eğitim ihtiyaçlarını nasıl giderilebilir?

Stratejik Hedef-3: Öğrencilerin ihtiyaçlarının karşılanması için Milli Eğitim Bakanlığından online ders verecek Özel eğitim öğretmeni sağlanması

Stratejik Amaç-4: Pandemi sürecinde yabancı öğrencilerin online eğitime alışması ve dil sorunu nasıl çözülür?

Stratejik Hedef-4: Yabancı öğrenciler ve veliler için online Türkçe dil kursu düzenlenmesi sağlamak ve dil sorununu çözmek.

\subsection{Eğitim ve Öğretimde Kalitenin Artırılması (Tema II)}

Pandemi sürecinde Eğitim ve öğretimde kalitenin artırılması başlığı eğitim ve öğretim faaliyetinin hayata hazırlama aşamasında yapılacak çalışmaları kapsamaktadır. Bu tema altında akademik başarı, öğrencilerin okulumuzun adını gündeme getirilebileceği online yarışmalar ile mezun oldukları zaman çok yönlü gelişimlerini sağlayacak onların ilerde istihdam ve meslek edindirmeye yönelik faaliyetleri yer almaktadır.

Stratejik Amaç 1: Pandemi sürecinde ortaöğretim kurumlarında öğrenciler ve öğretmenler okulun adını gündeme getirilebileceği farklı online projelerde ve etkinliklerde nasıl rol alabilirler?

Stratejik Hedef 1: Okulun adını gündeme getirilebileceği online yarışmalara katılabilirler. Ayrıca basın yayın organlarından destek isteyebilirler.

Stratejik Amaç 2: Pandemi sürecinde ortaöğretim kurumlarının akademik başarısını nasıl yükseltilebilir?

Stratejik Hedef 2: Öğretmenlerin ve öğrencilerin online eğitimi başarılı şekilde kullanmaları sağlanarak yap1labilir.

\subsection{Kurumsal Kapasite (Tema III)}

Pandemi sürecinde kurumsal kapasiteyi yükseltmek için yaşam boyu öğrenme anlayışı çerçevesinde, bulunduğumuz çağın eğitim anlayışına uygun fiziki ve teknolojik altyapı hizmetlerini sağlamaktır.

Stratejik Amaç-1: Pandemi sürecinde okulun ihtiyaçlara yönelik kurumun faaliyet alanlarını destekleyici fiziki ve teknolojik altyapı hizmetleri nasıl sağlanabilir?

Öğretmenlerin ve yöneticilerin eğitimde daha etkili ve nitelikli rol almalarını ve teknolojik aletleri daha kolay kullanmaları nasıl sağlanabilir?

\section{SONUÇLAR VE ÖNERILLER}

Görüşme formlarında yer alan sorular ve bu sorulara verilen cevaplar Tablo 6.'da frekans değerleri ve yüzdelikleriyle aktarılmaktadır. 
Tablo 6. Stratejileri Belirleme Görüşme Formu Cevapları

\begin{tabular}{|c|c|c|c|}
\hline SORULAR & CEVAPLAR & Frekans (n) & $\%$ \\
\hline $\begin{array}{l}\text { 1-Pandemi sürecinde kurumlarınızda eğitim ve } \\
\text { öğretime erişim nasıl sağlandı? }\end{array}$ & $\begin{array}{l}\text { Online yoklama defterlerinden } \\
\text { kontroller yaplmalıdır. }\end{array}$ & 3 & 10 \\
\hline $\begin{array}{l}\text { 2--Pandemi sürecinde kurumlarınızda eğitim ve } \\
\text { ögretimde kaliteyi nasıl artırdınız? }\end{array}$ & $\begin{array}{l}\text { Okul yöneticileri ve ögretmenlere } \\
\text { Online Hizmetiçi eğitim kullanarak } \\
\text { eğitimi kaliteli ve zevkli hale gelmesi } \\
\text { çalışmaları ile yapılmaya çalışıldı. }\end{array}$ & 5 & 17 \\
\hline $\begin{array}{l}\text { 3-Pandemi sürecinde kurumsal kapasiteyi nasıl } \\
\text { sağladınız? }\end{array}$ & $\begin{array}{l}\text { Hizmet içi, E-öğrenme ortamlarl ve } \\
\text { ögretmen ve ögrencilere } \\
\text { olabildiğince teknolojik destek } \\
\text { sağlayarak }\end{array}$ & 6 & 21 \\
\hline $\begin{array}{l}\text { 4-Pandemi sürecinde öğrencilerinizin online } \\
\text { derslere devam devamsızlıkları nasıl daha kolay } \\
\text { alınabilir? Devamsızlık takibi nasıl kontrol } \\
\text { edilebilir? }\end{array}$ & $\begin{array}{l}\text { Müdür Muavinlerinin } \\
\text { yoklama fişlerini düzgün } \\
\text { işlemekilde } \\
\text { şelidir }\end{array}$ & 2 & 7 \\
\hline $\begin{array}{l}\text { 5- Maddi durumu yetersiz olan öğrencilerin } \\
\text { uzaktan eğitim giderleri için kaynaklar nasıl } \\
\text { sağlanabilir? }\end{array}$ & $\begin{array}{l}\text { Maddi durumu yetersiz ögrencilerin } \\
\text { uzaktan eğitim giderleri için } \\
\text { yardımsever işadamları veya hayır } \\
\text { kurumlarından ögrenci sayısına göre } \\
\text { maddi destek istenmelidir. }\end{array}$ & 2 & 7 \\
\hline $\begin{array}{l}\text { 6- Pandemi sürecinde özel eğitime ihtiyaç duyan } \\
\text { öğrenciler eğitim ihtiyaçlarını nasıl giderilebilir? }\end{array}$ & $\begin{array}{l}\text { Ö̈̆grencilerin } \quad \text { ihtiyaçlarının } \\
\text { karşılanması için Milli Eğitim } \\
\text { Bakanlı̆̆ından online ders verecek } \\
\text { Özel eğitim öğretmeni sağlanmast. }\end{array}$ & 1 & 3 \\
\hline $\begin{array}{l}\text { 7-Pandemi sürecinde yabanc1 öğrencilerin dil } \\
\text { sorununun nasıl çözülebilir? }\end{array}$ & $\begin{array}{l}\text { Yabancı ögrenciler ve velileri için } \\
\text { Online Türkçe dil kursu } \\
\text { düzenlenmesi }\end{array}$ & 1 & 3 \\
\hline $\begin{array}{l}\text { 8-Pandemi sürecinde ortaöğretim kurumlarının } \\
\text { akademik başarısını nasıl yükseltilebilir? }\end{array}$ & $\begin{array}{l}\text { Bakanlık tarafindan okul yöneticileri } \\
\text { ve öğretmenlere online eğitimin } \\
\text { kullanılabilmesi için gerekli hizmet } \\
\text { içi eğitim verilmesinin sağlanması ile } \\
\text { yapılabilir. }\end{array}$ & 4 & 14 \\
\hline $\begin{array}{l}\text { 9-Pandemi sürecinde ortaöğretim kurumlarında } \\
\text { öğrenciler ve öğretmenler okulun adını gündeme } \\
\text { getireceği farklı online projelerde ve etkinliklerde } \\
\text { nasıl rol alabilirler? }\end{array}$ & $\begin{array}{l}\text { Okulun adını gündeme } \\
\text { getirebilecekleri Online yarışmalara } \\
\text { katılabilirler. Ayrıa basın yayın } \\
\text { organlarından destek isteyebilirler. } \\
\text { Bunlara ek olarak online çeşitli } \\
\text { yardım etkinlikleri ve farkındalık } \\
\text { haftası günleri düzenleyerek dikkat } \\
\text { çekebilirler. }\end{array}$ & 1 & 3 \\
\hline $\begin{array}{l}\text { 10-Pandemi sürecinde okulun ihtiyaçlara yönelik } \\
\text { kurumun faaliyet alanlarını destekleyici fiziki ve } \\
\text { teknolojik altyapı hizmetleri nasıl sağlanabilir? }\end{array}$ & $\begin{array}{l}\text { Okulun ihtiyaçlara yönelik kurumun } \\
\text { faaliyet alanlarını destekleyici fiziki } \\
\text { ve teknolojik altyapı hizmetleri (MEB } \\
\text { tarafindan Fiber Optik sisteme geçiş, } \\
\text { E-Öğrenme, Dijital Eğitim } \\
\text { Olanaklarl) ortamlarının sağlanması } \\
\text { ile yapılmaya çalışıldl. }\end{array}$ & 4 & 14 \\
\hline Toplam & & 29 & 100 \\
\hline
\end{tabular}

Tablo 6.'daki verilerden de görüldüğü üzere kurumlarda stratejik planlama yapılırken en önemli etkenin Hizmetiçi eğitim, "Eğitim öğrenme ortamlart ve ögretmen ve ögrenciye olabildiğince teknolojik destek" sağlanmalıdır $(\mathrm{n}=6 ; \mathrm{p}=\% 21)$. İkinci önemli etkenin "okul yöneticileri ve ögretmenlere online hizmetiçi 
eğitimlerdeki materyalleri kullanarak eğitimi kaliteli ve zevkli hale getirmeleri çalışmaları" olmuştur $(\mathrm{n}=5 ; \mathrm{p}=\% 17)$. Üçüncü sıra aynı puanla iki tane faktörün etkili olduğu görülmüsstür. "KKTC Milli E ğitim Bakanliğl (MEB) tarafindan okul yöneticileri ve ögretmenlere gerekli online hizmetiçi eğitimin verilmesi" ile sağlanmalıdır. Birde "Okul ihtiyaçlarına göre kurumun faaliyetlerini destekleyici fiziki ve teknolojik altyapı hizmetleri sağlanması" ile yapılabilir $(\mathrm{n}=4 ; \mathrm{p}=\% 14)$. Son sırada aynı puanla 3 cevap yer almıştır. Bunlar "Yabancı ögrenciler ve velileri için Online Türkçe dil kursu düzenlenmesi ", "Okulun adını gündeme getirebilecekleri online yarışmalara katılma ve basın yayın organlarından destek alınmas1 ". Ayrıca, "online çeşitli yardım etkinlikleri ve farkındalık haftası günleri düzenleme". "Özel eğitim ögrencileri için online ders verecek Özel eğitim öğretmenlerinin MEB tarafindan săglanması". (n=1; $\mathrm{p}=\% 3)$.

Sonuç olarak 2019-2020 Bahar döneminde Dijital Eğitime geçiş ve MEB tarafindan oluşturulan Eğitim Politikaları ve buna bağlı yaşanan aksaklıklar tespit edilmiş MEB bünyesinde kurulan moodle sistem ile entegre çalışacak video konferans programları geliştirilmiştir. Öğretmenler için hizmet içi eğitimler gerçekleştirilmiş ve öğretmenlerin uzaktan eğitim sürecinde öğrencilere ulaşabilmeleri sağlanmıştır.

$\mathrm{Bu}$ süreçte yardıma ihtiyacı olan yardım etmek için çeşitli kurum ve kuruluşlar kampanyalar başlatmıştır.

Tablet, bilgisayarların ve diğer teknolojik aletlerin KDV oranının düşürülmesi ve bankaların borç faiz yüzdelerini düşürerek öğretmen ve öğrencilerin teknolojik araç gereç alım gücüne destek verilmiştir.

Türkiye'deki eğitim programı olan EBA ( Eğitim Bilişim Ağı'nın) KKTC'deki öğretmenlerin hizmetine açılması ile öğretmenlerin tüm kaynaklardan ve hizmet içi eğitimlerden yararlanması sağlanmıştır.

\subsection{Ortaöğretim Kurumları İçin Strateji Önerileri}

Kurumlarda başarılı bir stratejik plan yapabilmemiz için aşağıdaki stratejileri uygulamamız gerekmektedir.

- Ortaöğretim kurumlarının genelde temel stratejisi ülkelerini hedeflerini gerçekleştirebilecek ve nitelikli öğrenci, yetiştirmektir. Pandemi sürecinde de aynı amaç doğrultusunda eğitim kurumları teknolojik altyapılarını geliştirmeli ve aynı hedefe ulaşmak için tüm paydaşları ile birlikte çalışmalıdır.

- Pandemi sürecinde kurumların online eğitimin gereksinimlerinin karşılanabilmesi için MEB verdiği bütçe dışında pek fazla kaynağı olmamasından ötürü istenilen hedefleri yakalanması zordur. Bunun için farklı alternatifler yaratması gerekmektedir.

- Pandemi sürecinde Stratejik amaçlar, hedefler ve bu hedeflere ulaşabilmek için yapılacak eylemler planladıktan sonra planın bütçe oluşturma kısmına geçilmelidir. Her bir hedefi gerçekleştirmek için eylemler teker teker incelenmeli ve maddi kaynak bulunmalıdır. Böylece bir yıllık tahmini bütçe çıarılmalı, ardından 2 yıllık ve 5 yıllık hedeflere ulaşabilmek için bütçede ne gibi önlemler alınması gerektiğine ve hangi maddelerin öncelik taşıdığına karar verilmelidir.

- Stratejik planların izlenmesi ve değerlendirilmesi çalışmalarına 2020-2021 sonunda kadar devam edecektir. İlk izlenimler Haziran 2020 tarihinde tamamlanmıştır. (Tavsiye edilen süre 6 aydır.) İzleme ve değerlendirme aşamasında amaçlar ve hedeflere ne kadar yaklaşıldığı, hangi alanlarda eksiklikler olduğu ortaya çıkarılmıştır. Yapılan incelemeler sonucunda yılsonu değerlendirme raporu hazırlanacaktır. Yılsonu değerlendirme raporu sonuçlarına göre SWOT analizi yeniden gözden geçirilecek ve güncellenecektir. Değerlendirme raporu ve SWOT analizine göre bir sonraki yılın stratejik planı yeniden oluşturulması beklenmektedir.

- Okullarda Pandemi sürecinde stratejik planların etkili olması için dikkat edilmesi gerekenler: Okul yönetiminin öncelikle stratejik plan geliştirmesi ve bunu yaparken stratejik düşünerek karar vermesi, 
çevresel faktörleri analiz ederek kurumlarının potansiyellerini ortaya çıkarması ve geliştirmesi gerekmektedir.

- Okulların gelişimine katk1 sağlayacak olan stratejik planda maddi ve maddi olmayan tüm kaynakların en verimli bir şekilde kullanılması ve gerektiğinde stratejik planlarda değişiklikler yapılabilmesi gerekmektedir.

\subsection{Milli Eğitim Bakanlığı İçin Strateji Önerileri}

- Türkiye'de olduğu gibi KKTC'de de Milli Eğitim Bakanlığı tarafindan Stratejik Geliştirme Başkanlığı kurulmalı ve gerekli düzenlemeler yapılarak olası durumlar için okullara yönelik genelgeler oluşturulmalıdır.

- MEB bünyesinde oluşturulacak bu birim sayesinde strateji planlama, proje çalışmaları ve eğitim araştırmaları konularında üreten ve üretimini paylaşan uzmanlarla her okulun stratejik planlama oluşturması koordine edilmeli ve gerekli hizmetiçi eğitimler verilmelidir.

- Hazırlanacak olan genelge ile geleceğe dönük olarak stratejik planlarını hazırlamaları ve bütçelerini planda öngörülen misyon, vizyon, amaç ve hedefleri ile uyumlu olacak biçimde performans programlarına dayalı olarak oluşturmalıdır.

- Bütce hazırlama ve uygulama süreçlerinde mali disiplinin sağlanması kaynakların stratejik önceliklere göre dağıtılması, bu kaynakların etkin kullanılıp kullanılmadığının denetlenmesi gerekmektedir.

$\mathrm{Bu}$ çalışma sonucunda, kurumlarda olması gereken stratejik planlama sürecinin basamakları dikkate alınarak pandemi sürecinde ortaöğretim kurumları için olası 2020-2025 yılları stratejik planı hazırlanmaya çalışılmıştır.

\section{Bilgilendirme / Acknowledgement:}

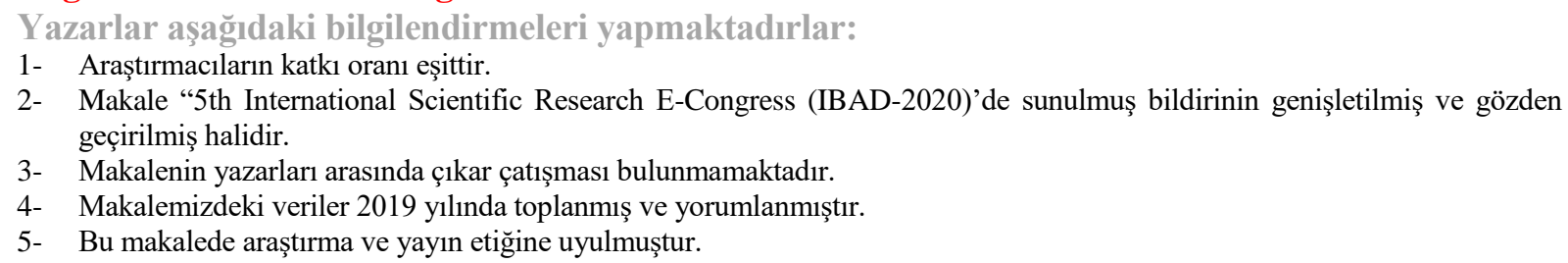

\section{KAYNAKÇA}

Aksu, M. (2002). Eğitimde stratejik planlama ve toplam kalite yönetimi. Ankara: Anı Yayınc1lık

Aktan, C.C. (1997). Değişim ve yeni global yönetim. İstanbul: Mess Yayınları.

Aktan, C.C. (2008). Stratejik yönetim ve stratejik planlama. ÇEIS Çimento Endüstrisi İşverenleri Sendikası Yayınaktanı, 22, 4-21.

Arabacı, İ. B. (2018). Eğitim örgütlerinde stratejik planlama. Ankara: Pegem Yayınlar1.

Barut, B. (2020). Swot analizi nedir? 27 Ağustos 2020 tarihinde https://medium.com/@berfinsubarut/swot-anali\%CC\%87zi\%CC\%87-f03c3d32fd2d adresinden erişildi. 
Bell, L. (2004). Strategic planning in primary schools: A tale of no significance? Management in Education, 18, 33-36.

Gönüllü, A. (2008). Kamu yönetiminde stratejik planlamaya geçiş: Mersin Milli Eğitim Müdürlüğ̈̈ örneği. Yayımlanmamış yüksek lisans tezi, Mersin Üniversitesi, Sosyal Bilimler Enstitüsü, Mersin.

Memduhoğlu, H. ve Uçar, İ. (2012). Yönetici ve öğretmenlerin stratejik planlama algısı ve okullarda mevcut stratejik planlama uygulamalarının değerlendirilmesi. Mehmet Akif Ersoy Üniversitesi Eğitim Fakültesi Dergisi, 1(23), 234-256.

Miles, M. B. \& Huberman, A. M. (1994). Qualitative data analysis: An expanded sourcebook. (2nd ed). Thousand Oaks, CA: Sage.

Nartgün, Ş. S. (2003). Stratejik planlama ve eğitim. C. Elma ve K. Demir (Editör). Yönetimde çağdaş yaklaşımlar içinde. 277-300. Ankara: Anı Yayıncılık.

OECD (2020). 2020 COVID-19 pandemisine karşı eğitimde atılabilecek adımlara rehberlik edecek bir $\begin{array}{lllll}\text { çerçeve. } & 27 & \text { Ağustos } & 2020 & \text { tarihinde }\end{array}$ https://globaled.gse.harvard.edu/files/geii/files/framework_guide_v4_tr.pdf adresinden erişildi.

Reiger, B. J. (1993). Strategic planing and public schools: An evolving practice. Educational Planning, 9 (4), $14-22$

Reimers, F. ve Schleicher, A. (2020). Covid-19 pandemisine karşı eğitimde alınabilecek adımlara rehberlik edecek bir çerçeve. 3-40(1), 38-50.

Tokat Gaziosmanpaşa Üniversitesi (2019). 2019-2023 Stratejik planı, Tokat.

Yanpar Y. T., Kılıç F. ve Üredi L. (2010). Stratejik planlama uygulamalarına ilişkin ilk ve ortaöğretim okul müdürlerinin görüşleri. Uluslararası Avrasya Sosyal Bilimler Dergisi, 1(1), 38-50.

2020 COVID-19 pandemisine karşı eğitimde atılabilecek adımlara rehberlik edecek bir çerçeve. 25 Ağustos 2020 tarihinde http://www.oecd.org/termsandconditions adresinden erişildi. 